\title{
What enables local governments to mainstream climate change adaptation? Lessons learned from two municipal case studies in the Western Cape, South Africa
}

\author{
Lorena Pasquini \\ University of Cape Town \\ Gina Ziervogel \\ University of Cape Town \\ Richard Cowling \\ Nelson Mandela Metropolitan University \\ Clifford Shearing \\ University of Cape Town
}

Final draft of paper subsequently published as:

Pasquini, L., Ziervogel, G., Cowling, R.M. and Shearing, C. 2015. What Enables Local Governments to Mainstream Climate Change Adaptation? Lessons Learned from Two Municipal Case Studies in the Western Cape, South Africa. Climate and Development, 7(1): 60-70. 


\begin{abstract}
Municipalities represent a key opportunity for implementing local adaptation to the impacts of climate change. Most research has focused on the barriers to climate change adaptation, and little research exists that considers the conditions under which a municipality is able to initiate the process of climate adaptation mainstreaming. Through a case study of two municipalities in the Western Cape of South Africa, this paper identifies the factors that enable action to be taken at the local government level. The presence of dedicated environmental champions is key, particularly political leadership. Experiencing the costs of climate change often provides the strongest initial catalyst for action, and is aided by the recognition that the local environment has value. Access to a knowledge base, the availability of resources, political stability and the presence of dense social networks all positively affect adaptation mainstreaming. It is these enabling factors that other government levels and stakeholders need to support with different interventions. We draw attention to two under-researched topics, the effect of political instability on municipal functioning, and the effects of social network characteristics on facilitating institutional change.
\end{abstract}

Keywords: adaptation; local government; mainstreaming; climate change; governance

\title{
1. Introduction
}

In recent years, increasing attention has been paid to climate adaptation planning and policy, as the applied nature of adaptation means that much of the burden of action has been shifting from the scientific realm to governments at all levels, development organizations, NGOs, businesses, households, communities, land users and others that will need to respond to the negative impacts of a changing climate (Eakin \& Lemos, 2006: 7). Local governments, as the level of government generally most directly responsible for planning and management at the urban and local scale, have a key role to play in addressing climate change adaptation. Especially urban areas in developing nations are increasingly vulnerable to climate change impacts such as floods, heat waves, droughts and so forth (e.g. Roy, 2009; Romero-Lankao \& Dodman, 2011; Carmin et al., 2012). However, these areas face both challenges and opportunities in developing climate change responses, and in mainstreaming them with development goals (e.g. Roy, 2009; Romero-Lankao \& Dodman, 2011).

For all the promise of the growing involvement of urban areas in addressing climate change, an increasingly established literature on the barriers to adaptation (e.g. Measham et al., 2011; Baker et al., 2012; Ziervogel \& Parnell, 2012) shows that local governments face numerous constraints, including knowledge, regulatory and capacity barriers, among others. Although there are examples of cities that have been the sources of initiatives and 
policies on climate change adaptation (e.g. Sanchez-Rodriguez, 2009; Rosenzweig \& Solecki, 2010; Hardoy \& Romero Lankao, 2011; Carmin et al., 2012), research has not systematically examined successful cases of local government adaptation, and isolated the factors that enable a municipality to initiate the process of climate adaptation mainstreaming - i.e. the process of including climate adaptation considerations into governmental policies and practices (although Carmin et al. (2012) take an important step in this direction). A more integrated understanding of what factors at the municipal level enable municipalities to address and mainstream climate change issues is required. Importantly, examples below the level of major cities, i.e. at the level of small cities and towns, are also required. Existing cases of successful adaptation mainstreaming reported in the literature, in both developed and developing countries, are focused on major metros, which can lead to the perception that only municipalities governing the biggest cities are able to take independent initiative on the problems of climate change adaptation.

Here we propose a set of enabling factors that we suggest lie behind the ability of municipalities to mainstream climate change adaptation, based on a case study of both a large (City of Cape Town) and a small municipality (Hessequa) in the Western Cape Province of South Africa. After providing a brief context of the two municipalities, we present and discuss the conditions that led these two municipalities to begin to consider and respond to the problems posed by climate change.

\section{Case studies and methods}

The City of Cape Town (CCT) is situated on the southern peninsula of the Western Cape, spans $2,461 \mathrm{~km}^{2}$, and has a population size over 3 million. By contrast, Hessequa is a highly-rural municipality of $5,730 \mathrm{~km}^{2}$ with a total population size of c. 50,000 people (with around 12,000 people in its biggest town, Riversdale). It is located on the Indian Ocean coast of the Western Cape Province. Global climate modelling suggests that there will be significant climate change impacts in the Western Cape Province (Midgley et al., 2005). The CCT has been the subject of a substantial amount of research on climate change adaptation, research that shows the city to be one of South Africa's early adapters (Mukheibir \& Ziervogel, 2007; Ziervogel et al., 2010; Ziervogel \& Parnell, 2012). Hessequa, by contrast, has received no prior attention in the climate change or adaptation literature.

The data presented here are drawn from a wider research project investigating various aspects of climate change adaptation in eight municipalities in the Western Cape: Cape Town, Eden district, Swartland, Hessequa, Mossel Bay, George, Oudtshoorn and Knysna municipalities. Semi-structured interviews were conducted from July 2009 to March 2010 with three officials and three councillors from each municipality. The interview 
questions focused on the experience of municipalities with extreme weather events, the knowledge and beliefs of respondents on climate change and adaptation issues, as well as municipal actions in this regard (Box 1). However, many of the findings we present here were derived as a result of open discussions generated by the questions. To complement the interviews, we additionally gathered and reviewed key municipal documents: Integrated Development Plans (a plan for a municipality that gives an overall framework for development), Spatial Development Frameworks (which set out the "spatial vision" for the municipality), Annual Reports and Budgets. We examined other relevant information where it was available, such as municipal websites and a variety of documents supplied by respondents.

The interviews were conducted and recorded (with permission) by the lead author. All interviews took place on site, mostly at council offices, and lasted on average between half an hour and one and half hours. Participants were contacted by email or telephone and told about the full nature of the study and why they were selected for participation; they were also assured of full confidentiality. Interviews were transcribed, coded and analysed using qualitative techniques. Transcribed texts were initially coded by labeling related data with numerous category codes. In a second stage, coding categories were eliminated, combined, or subdivided to identify repeating ideas (the same idea expressed by different respondents) and themes (a larger topic that organizes or connects a group of repeating ideas) that connected codes.

Out of the eight municipalities examined, CCT and Hessequa had developed the most concern and attention to the problems of climate change, and our analysis here focuses on the reasons why these two municipalities, despite their vast contextual differences, share this concern. In our analysis we draw upon the (relatively) substantial knowledge on adaptation that is available for the CCT (to which the second author has largely contributed to) and on the knowledge generated during a repeat visit to the Hessequa municipality in 2012, which was partially prompted by the difference in amounts of research performed on the two municipalities. During the repeat visit, another six officials and six councillors were interviewed using the procedures outlined above. Although these interviews focused more specifically on issues tied to politics and leadership change within the municipality, and their effects on climate governance (and will be reported elsewhere), the interviews generated data relevant to the analysis we present here. 
Box 1. Broad topics for discussion in the interview guide (some topics have been omitted as they fall outside the scope of this paper)

\begin{tabular}{|c|c|}
\hline Broad topic & Main question categories \\
\hline $\begin{array}{l}\text { The municipality's and respondent's } \\
\text { experience with extreme weather events } \\
\text { (floods, droughts and storm surges) }\end{array}$ & 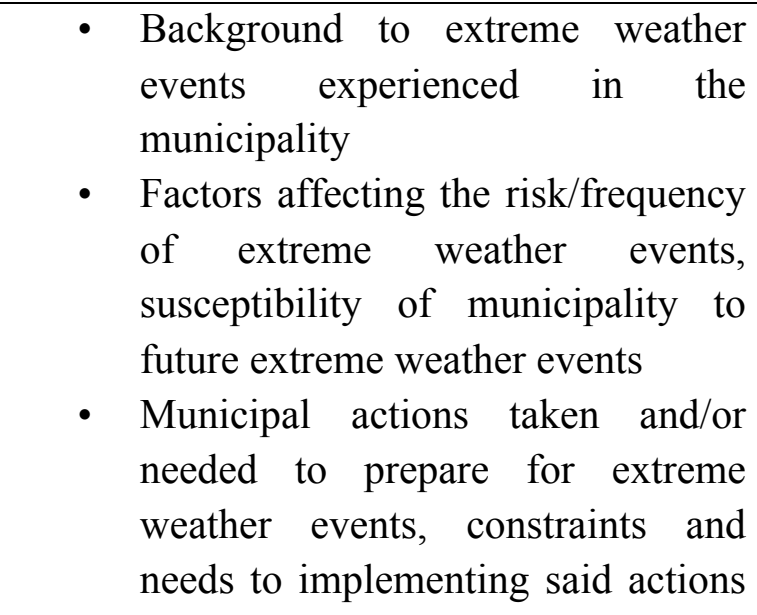 \\
\hline $\begin{array}{l}\text { The respondent's knowledge and beliefs } \\
\text { regarding climate change, adaptation, and } \\
\text { ecosystem-based adaptation }\end{array}$ & $\begin{array}{l}\text { - The respondent's belief about } \\
\text { whether climate change is } \\
\text { occurring, and the expected effects } \\
\text { - The respondent's definition of } \\
\text { climate change } \\
\text { - The respondent's definition of } \\
\text { adaptation } \\
\text { - The respondent's knowledge of } \\
\text { ecosystem-based adaptation } \\
\text { - The respondent's sources of } \\
\text { knowledge on climate change, } \\
\text { extreme weather events and } \\
\text { adaptation issues } \\
\text { Positions or departments believed } \\
\text { to be the best-placed to deal with } \\
\text { climate change }\end{array}$ \\
\hline $\begin{array}{l}\text { The municipality's actions on climate } \\
\text { change and adaptation }\end{array}$ & $\begin{array}{l}\text { - Municipal actions taken and/or } \\
\text { needed to prepare for climate } \\
\text { change, constraints and needs to } \\
\text { implementing said actions }\end{array}$ \\
\hline
\end{tabular}




\begin{tabular}{|c|c|}
\hline & $\begin{array}{l}\text { - Actions taken by the municipality } \\
\text { that can be classed as ecosystem- } \\
\text { based adaptation } \\
\text { - Existence (or otherwise) of } \\
\text { municipal plans or policies on } \\
\text { climate change/adaptation } \\
\text { - Existence (or otherwise) of a } \\
\text { dedicated post/department for } \\
\text { dealing with climate change issues }\end{array}$ \\
\hline $\begin{array}{l}\text { Relevant organizational/social issues in the } \\
\text { municipality }\end{array}$ & $\begin{array}{l}\text { - Political composition and stability } \\
\text { of the municipality } \\
\text { - Collaboration between positions or } \\
\text { departments in the management of } \\
\text { extreme weather events } \\
\text { - Effect of the municipality's actual } \\
\text { or hypothetical engagement with } \\
\text { climate change issues on the } \\
\text { municipality's status with other } \\
\text { levels of government, and within } \\
\text { the municipality's communities } \\
\text { Existence (or otherwise) of an } \\
\text { environmental department, } \\
\text { composition and mandate }\end{array}$ \\
\hline
\end{tabular}

\section{Results and Discussion}

Despite the vast differences between them, our research shows the two municipalities to have developed comparable concern with the problems of climate change. The actions planned or taken by the two municipalities relevant to climate adaptation are summarized in Table 1. At the time of study, both municipalities were working on draft climate adaptation plans. Additionally, some of the strongest knowledge and recognition of climate change was found in these two municipalities (as compared against the other eight in the wider research project). Finally, though mitigation falls outside the scope of our paper, we note that both municipalities had started with mitigation plans and/or actions, also unusual compared to the other municipalities we surveyed. Below we discuss the key factors that enabled our case study municipalities to address climate adaptation issues.

Table 1. Actions taken by the case study municipalities relevant to climate change adaptation (not intended as a definitive list of all adaptation-relevant initiatives taken by 
the municipalities, as due to the focus of the interviews, the actions encountered mainly dealt with extreme weather event management).

\section{Cape Town}

- Inter-departmental collaboration, e.g. a Flood and Storms Planning Task Team (a multi-disciplinary team of City and supporting external agencies) established to manage flood risk reduction and response measures, established in 2008

- Participation of municipal staff and politicians in climate-related conferences, workshops and/or courses

- Commissioning of climate-related research and studies, e.g. a Framework for Adaptation to Climate Change (in response to the potential short- to medium-term

- impacts of climate change in the metropolitan area); a sea-level rise study to model and understand the ramifications of predicted sea-level rise and increased storm events for the CCT; a study on predicted climate change impacts on the intensities and frequencies of storm rainfall

- Implementation of weather early-warning systems

- Implementation of flood risk reduction measures e.g. regular maintenance of storm-water drainage systems; plans for upgrading storm-water infrastructure

- Updating of flood lines

- Establishment of a Disaster Management plan

- Establishment of a flood plan and river corridor management policy

- Establishment of relevant advisory committee on climate change: establishment of a Climate Change Think Tank (in 2009) for informing, shaping, and driving the implementation of local-level climate change policies, programmes and interventions

- Control of development: identification of development at risk; new development curtailed (discussion in city densification policies); control of informal settlement 
spread

- Awareness-raising (relevant to adaptation) undertaken among communities

- Collaboration with third-party partners to source adaptation funding

\section{Hessequa}

- Participation of municipal staff and politicians in related conferences, workshops and/or courses

- Conducting relevant research and studies, by working in partnership with other institutions e.g. research on future sustainable farming directions

- Implementation of weather early-warning systems

- Implementation of flood risk reduction measures e.g. regular maintenance of storm- water drainage systems; construction of additional storm-water drainage systems

- Implementation of fire risk reduction measures e.g. establishing fire-breaks

- Implementation of drought risk reduction measures e.g. issuing water tanks to previously disadvantaged rural areas

- Implementation of food insecurity risk reduction measures: establishing food gardens in previously disadvantaged areas

- Implementation of disaster risk reduction measures through ecosystem-based adaptation e.g. establishment of municipal nature reserves; encouraging private landowners to set up nature corridors and conservancies; working with conservation bodies to conserve the environment and to restore the wetlands; encouraging communities in the municipality to restore natural vegetation

- Addressing water scarcity through water supply management: sinking boreholes; clearing alien invasive vegetation; requiring new developments (over a certain size) to make provision for a water tank

- Addressing water scarcity through water demand management e.g. awareness campaigns to encourage water saving (for e.g. by establishing less waterdemanding gardens)

- Establishment of a Disaster Management plan (though all municipalities are mandated to do so, many are lagging behind in the task)

- Control of development: identification of development at risk; control of informal settlement spread

- Awareness-raising undertaken among communities e.g. school education programmes; radio \& newsletter programmes 


\subsection{Leadership}

Leadership emerged as a key factor driving climate change mainstreaming. In the CCT, adaptation leadership has been provided by senior officials of the environmental department, and political leadership has not played a particular role. Achievements in environmental and sustainable development issues in this case have taken some time to build up (since 1998). In the Hessequa municipality, instead, adaptation mainstreaming was driven by political champions, and this case study reveals the importance of senior political leadership for driving rapid change. Respondents indicated that in less than a five-year term, two senior councillors were able to implement a mind-set change in the municipality that led directly to initiatives geared towards sustainable development. What is especially instructive of the Hessequa municipality case is the demonstration of the importance of obtaining the buy-in on sustainable development of the entire structure of the municipality, i.e. of the rest of the Council and all the municipal departments. Isolating climate action to a small group of specialists within a municipality is unlikely to yield the necessary level of transformation required for sustainable development at the municipal scale (e.g. Burch, 2010; Measham et al., 2011; Baker et al., 2012).

In explaining the rise of urban climate governance, the literature has drawn attention to the importance of individual politicians or officials, especially the former (e.g. Qi et al., 2008; Sanchez-Rodriguez, 2009; Anguelovski \& Carmin, 2011; Measham et al., 2011; Carmin et al., 2012;). Although climate adaptation can be driven from within the administration (as we found in the CCT), it is important to recognise that allocating adequate resources and setting goals rest strongly in the hands of elected politicians, hence the presence or lack of support from political leaders can markedly affect climate mainstreaming. Our findings in Hessequa highlight the importance of political champions over champions located in administrative structures, and of senior political figures (such as mayors and deputy mayors) over junior political champions. Senior political leadership can bring about rapid change in a municipality in terms of climate mainstreaming, and importantly, can lead to a coordinated approach by bringing municipal officials together across internal divisions. In our study, we found that environmental champions were able to catalyse a path shift towards sustainable development because of a recognition of the costs of climate change, as we explain below.

\subsection{Cost}

The recognition that climate change can result in costly impacts is also a recognition of the cost to maintaining current, non-adaptive development policies and practices. This understanding has the potential to galvanise municipal action on climate change, as in Hessequa's case.

Basically we've been right in the thick of things, because at the moment [...] we [are] 
currently a disaster area [...]. We started off here [as a council] in 2004. We had the first big floods [...] When these big floods started to occur, which they now [have] been regularly, every year we have floods, but there was significant damage over the period 2004, 2008 and 2009 [...] Well, I think we've been on a path, starting at the beginning of our term, to try and understand what has caused all of this, and we've firmly adopted a policy based on ... sustainable development and management [...] so we understand that the reasons are definitely due to climate change and all those issues around that. Councillor, Hessequa municipality.

This unusual experience with costly disasters led the council of the municipality to look into the detail of the causes and management of environmental disasters, resulting in the appointment, among other changes, of both a disaster management official and an environmental officer. Significantly, organizational change required repeat experience with high cost disasters to be implemented. One of the political champions in the municipality commented that organizational and mind-set change had been slow for the first year, until the municipality suffered further disasters that graphically illustrated what the champion had been "preaching" for a year.

But within that first year, you know, with the next floods - and I think it was then that the sewerage works washed away [...] - suddenly people said "I think ... you're right, there's something in this, we need to start planning for [climate change]". So ... [it] was maybe even a positive thing that we did have a number of incidents, to turn the non-believers into believers. Councillor, Hessequa municipality.

The fact that incurring a cost can drive behavioural change at both individual and organizational levels is not a surprising finding. Extreme weather events and disasters put pressure on decision-makers and therefore can catalyse organizational change (e.g. Pelling \& Dill, 2010; Anguelovski \& Carmin, 2011; Carmin et al., 2012; RomeroLankao, 2012). For instance, one of the triggers for getting support for climate adaptation work in Durban were the city's experiences with damaging extreme weather events from 2007 to 2009 (e.g. Ziervogel \& Parnell, 2012).

The fact that behaviour change often comes ex post facto is also unsurprising - given that it is human nature to discount the future. Trading off long-term rewards against shortterm gains is among the most difficult tasks in human decision-making, and humans often prefer smaller immediate rewards over larger future rewards, especially as the delay before receiving the reward increases, and when uncertainty about the future is high (e.g. Critchfield \& Kollins, 2001; Hirsh et al., 2008; Kalenscher \& Pennartz, 2008). Given the uncertainties surrounding climate change, and the fact that it will be some years before the full consequences are felt, municipalities are likely to find it easier to put off spending on adaptive options (thus realizing an immediate saving on the costs of adaptation) than 
to invest in them (which may or may not result in a greater saving on the costs of dealing with a possible future disaster). Of crucial importance is answering the question, how can municipalities become proactive on climate change, rather than reactive? In this regard, the experience of the CCT proves interesting. In some measure, the CCT has been proactive on climate change adaptation: though the metro has suffered some disasters, these were, by the City's own admission, relatively minor (although there were repeated instances of disasters e.g. storm surge, flooding and fires). Despite this, the City took action on climate change, without waiting for a large-scale disaster to occur (for a reminder of the actions planned or taken by the municipality, refer to in Table 1). In the CCT's case, it is likely that the presence of administrative champions was key to the proactive behaviour of the municipality. In all cases, the lead agency was the Environmental Resource Management department of the CCT, whose mandate is to lead the formulation and implementation of strategies and programmes for environmental sustainability. Though senior political champions are important for rapid change, champions with environmental knowledge and qualifications (found among the administration) can play an essential role in recognizing the need for change before the costs of maintaining a path of unsustainable development manifest.

Our job is to [...] try to get the message across that disasters are coming. It may not be next year, it may be [in] 10 years' time, [it] may be [in] 30 years' time, but it's coming, and if we plan for those disasters now from a climate change perspective, the impact of that disaster, and the cost to the City, is going to be far reduced than if we ... wait for that to happen without preparing for it. And the cost to the City is massive, it could bankrupt the City [...] so there's a great opportunity [...] to put in place measures now that would substantially reduce the impact of natural disasters on the City. Official, CCT municipality.

The appointment of qualified environmental staff is related to the resource availability of the municipality (related to institutional size, discussed in section 5): only the largest municipalities can afford a contingent of qualified staff like the CCT has. Their environment department comprises around thirty highly-qualified staff (with many more less qualified and unskilled workers). By comparison, in the other Western Cape municipalities we surveyed, there was provision for at most one highly-qualified environmental staff position. Further, the proactive behaviour of the CCT is very likely to be related to the presence of an easily- accessible knowledge base, discussed in section 4 .

\subsection{A 'valuable' environment, and recognition of this}

Related to the recognition of the costs of climate change, is the recognition that the natural environment of the municipal area has 'value'. This recognition stems from the broader concept of the valuation of ecosystem services (e.g. Costanza et al., 1997), now 
well-established in the ecological economics literature and practice (e.g GómezBaggethun \& Barton, 2013; www.naturalcapitalproject.org). The emergence of the concept of ecosystem- based adaptation, by which is meant the use of biodiversity and ecosystem services as part of an overall adaptation strategy, is fairly recent in the research and practitioner fields. Ecosystem-based adaptation means that, for example, flood risk should be addressed through catchment management and the maintenance of healthy ecosystems, rather than canalising of rivers in ever-larger concrete channels (Roberts et al., 2012: 169). It requires understanding the concepts of climate change, climate adaptation, and ecosystem services. The CCT is recognizing ecosystem services explicitly, as the following quote highlights.

I think certainly in the last four to five years there's been a much greater recognition across all ... line functions, [that] particularly in Cape Town, our economy is very dependent on our natural assets. Official, CCT municipality.

Most of the respondents at the City were familiar with the term 'ecosystem services', a highly-unusual finding in the context of the Western Cape municipalities examined. This recognition resulted in the commissioning of a study on creating a methodology to value the CCT's natural environment, and to develop a sound environmental business case for increased investment into the environment (City of Cape Town, 2012). The study explicitly valued, among other things, ecosystem-based adaptation to the natural hazards of fires, floods and storm surge (de Wit et al., 2009).

In Hessequa, although the understanding of the concept of ecosystem services was not nearly as developed as in the CCT, respondents nevertheless had developed an appreciation of the importance of the environment to their municipality, mainly in terms of sustaining their economy through tourism. However, due to their particular experience with floods and the fact that the Department of Agriculture was working to restore and rehabilitate the wetlands, respondents were also particularly aware of flood prevention as a natural ecosystem property, as the following quote illustrates.

Due to the old farming habits, we lost a lot of the ... sponge effect in the northern areas of the river. So ... where all those reeds and palmiet [Prionium serratum, a sedge-like plant with an important role in river ecology] grew, that kept the water there, [those were taken] out, so there's dongas [erosion gullies] now of ... ten, fifteen metres deep. So the water just comes flying down, and ... then the river changes its course, because of the ... severity of the [flow]. So we ... lost a caravan park [...] as [the river] washed away banks. Official, Hessequa municipality.

Recognition of 'value' in the natural environment, as well as understanding of the concepts of ecosystem services, are likely to be strongly related to the availability, in our case study municipalities, of a knowledge base on environmental issues, as discussed 
next.

\subsection{A knowledge base}

Despite the existence of climate initiatives, climate change remains a marginal issue for most decision-makers, which is not unexpected given the dearth of knowledge among decision-makers regarding climate change, and possible mitigation and adaptation responses (e.g. IDS \& Tearfund, 2006; Ziervogel et al., 2010; Hardoy \& Romero Lankao, 2011; Romero-Lankao, 2012;). The grey literature on adaptation highlights the need for information and awareness provision to achieve successful mainstreaming (e.g. IDS \& Tearfund, 2006; Dalal-Clayton \& Bass, 2009; SPC \& GTZ, 2010). Cape Town's progress on climate change mainstreaming is related to the presence of a strong knowledge base in the city, with numerous academics (a number of Universities and colleges are present) and consultants providing sources of both free and paid information. The Climate Change Think Tank, for example, brings together City representatives with academics and consultants. As another example, the availability of highly qualified consultants enabled the City to commission a plausible socioeconomic scenario for predicted sea level rise and storm surge, which led municipal decision-makers to draft a Coastal Protection Zone By-law to safeguard the City's coastline. The presence of this knowledge base is very likely to be behind the City's unusual (in relation to other municipalities) grasp of the concept of ecosystem services: consider the launch, in recent years, of the Urban Ecology CityLab programme by the African Centre for Cities of the University of Cape Town. This CityLab was envisaged as a space in which knowledge could be generated and shared between academics, civil society, and those governing the city (Anderson \& Elmqvist, 2012). Lowe et al. (2009, in Sanchez-Rodriguez, 2009) stress that one of the key characteristics of adaptation initiatives in large cities of the U.S. has been the collaboration of the scientific community through local universities in those initiatives. The Panel on Climate Change, comprised of academics and representatives from private industry, has been key to New York City's adaptation processes (Rosenzweig \& Solecki, 2010).

Although the rural Hessequa municipality has no higher educational institutions of note, and few consultants, it too was able to access a knowledge base. One of the senior political champions was allowed to attend modules of an environmental Master's degree at Stellenbosch University (in the Western Cape), and brought the information received back to the municipality. In addition to the information imparted during the course, the champion established links and contacts both with the University and other institutions, which resulted in further knowledge exchange partnerships. For instance, the municipality and the University went on to sign a Memorandum of Understanding to work together on sustainable development. As one example of the benefits of this collaboration, a study (undertaken in collaboration with some other institutions) was 
undertaken to research more economically- viable and environmentally-sustainable crops for the agricultural sector in the municipal area, in part because of the predicted impacts of climate change for the area.

Increased collaboration and communication between government actors and consultants and academics (as well as other actors) supports the strengthening of technical and institutional capacity (e.g. IDS \& Tearfund, 2006; Holgate, 2007; Ziervogel et al., 2010; Romero-Lankao, 2012;). The experiences of the CCT and Hessequa validate the notion that an integral component of successful climate mainstreaming rests on the creation of new relationships of knowledge production and exchange - and hence on the ready availability (or accessibility) to municipalities of sources of environmental knowledge. Problematically, however, the community of professionals and research on climate change is small throughout Africa (Kithiia, 2011).

\subsection{Institutional size}

Cities present a concentration of resources, which may in some cases translate into a higher capacity to act (Athey et al., 2007). While this hypothesis has not been tested per se, most municipalities portrayed as 'early adapters' (cf. Ziervogel \& Parnell, 2012) have so far been major cities. Certainly the experience of the CCT suggests that its large size, and its consequently large resource base, allows it to employ a substantial number of highly- qualified environmental staff and pay for consultants when necessary. At the other end of the scale lies the municipality of Hessequa, a municipality with a very small revenue (tax-paying) base. However, Hessequa's small size appears instrumental in providing the flexibility that was required to circumvent the problems of small budgets and lack of access to knowledge.

As discussed, strong political leadership was able to create an organizational mind-set change in the municipality. This process was very likely facilitated by the small staff complement of the municipality (450 people in total), and the fact that most political and managerial staff are located within one principal, two-storey building (with the majority of the remainder located in a neighbouring building), meaning that most of the municipal decision- makers are 'down the corridor' from each other. Compare this to the staff complement of the CCT, which numbers around 25,000 and is spread throughout the city (even the principal municipal building is made up of two blocks, one of which is 26 storeys high). For instance, the political champion that attended the environmental Master's courses had a council of 15 people to convince to allow her the time off and resources to attend (contrast this to a council of 221 people in the CCT).

Social networks affect the flow and quality of information, with actors relying on people they know rather than impersonal sources (e.g. Granovetter, 2005: 33). Norms (the shared ideas about the 'right way to behave') are also more firmly held the denser a social 
network is, where density refers to the proportion of possible connections among nodes that is actually present in the network (e.g. Tenkasi \& Chesmore, 2003; Granovetter, 2005). Greater density makes the probability of norms being encountered, discussed and fixed more likely, and larger groups have lower network density (all else being equal) than smaller networks (because people have limits on how many social ties they can sustain). Therefore, the larger a network, the lower is its ability to define and enforce norms (Granovetter, 2005). We suggest that Hessequa's small size and the fact that municipal actors are located in close physical proximity to each other created a denser social network than would be found in a large municipality such as the CCT, and thus greatly facilitated the spread and establishment of new environmental norms. This dense social network allowed the municipality to fight the pervasive 'silo mentality' problem, whereby institutional 'silos' that fail to institutionalize collaboration among departments and individuals are a historic problem (e.g. Burch, 2010; Roberts, 2011; Froestad et al., 2012). In support of our hypothesis is, for instance, the finding that respondents offered very similar (environmentally-related) sentiments and views to each other, often using very similar phrasing (despite the fact that they were all interviewed separately). Similarities in environmental norms were noted between councillors and officials, and between the two different visits to the municipality. The latter finding is particularly noteworthy given that an entirely new council was governing the municipality on our second visit, and yet it repeated sentiments expressed in the preceding visit by different councillors from a different political party. More detailed work of ours related to the role of social networks in municipal governance will be presented in forthcoming articles, as it is outside the scope of the current paper.

\subsection{Political stability}

In the course of our wider research as well as within our case study municipalities, we found political stability (in terms of the frequency with which the political alignment of the municipality shifted) to play an important role in the effectiveness and functioning of municipalities. Political instability is a consequence of party politics at the municipal level, which leads to political in-fighting and manoeuvring for the gain of a political party over others, rather than a focus on meeting the needs of residents and communities. Changes in the political alignment of a council (which can occur within the span of a five-year political term) significantly disrupt the operation of municipalities, through:

(i) Changes in vision at a political level, with municipal actions and resources typically being re-directed.

(ii) The frequent replacement of senior staff (further causing loss of continuity), with new officials appointed not on the basis of capacity, but of political alignment. Respondents felt that not only are these individuals not necessarily the most qualified, 
they also act according to the dictums of their political bosses, for fear of losing their jobs. In addition, the severance packages of outgoing senior staff, who sign five-year contracts, can be a heavy financial burden on the typically over-stretched municipal finances.

(iii) A variety of administrative issues: for example, decisions on council agendas have to be deferred while council structures and appointments are changed around, thus impacting on the implementation of municipal actions.

These changes can occur in some municipalities several times a year, strongly impacting municipal functioning. Political instability within South African municipalities was widespread when elected politicians were allowed to cross the floor (which refers to leaving one's political party and joining another political party) without losing their seat on council (e.g. McLaughlin, 2012). Legislation abolishing floor-crossing came into effect in January 2009. Although our fieldwork took place two years after this change (2010-2012), we found that many municipalities still battle with issues of political instability, which we postulate are due to the impact of by-elections. When a councillor dies, resigns from a party or council, no longer meets the requirements for being a councillor, or is otherwise expelled from a party or the council, a by-election is held. We presume that in municipalities where the ruling party is only narrowly in the lead (often the case in the Western Cape), such by-elections can have strong effects.

The fact that both City of Cape Town and Hessequa municipality were politically stable since 2004 (Hessequa) and since 2006 (Cape Town) has been an important condition for the municipalities to advance their environmental agendas, as exemplified by the following quote.

We've made quite a lot of progress in the last four years, and I think that's part of why we [are] suddenly getting more and more ... traction around these [environmental] issues, ... [it's because] we [are] dealing with the same politicians. I'm not saying the DA [Democratic Alliance] or the ANC [African National Congress] politicians are better, but you're dealing with a constant person ... [it] takes a lot of time to build that person's capacity and to get them to understand what you're on about ... so that's been hugely beneficial. Official, CCT municipality.

The fact that political stability is important independent of the political party in power is demonstrated by the fact that the two municipalities, at the time of study, were led by the two main opposing parties in South Africa, the DA in Cape Town and the ANC in Hessequa.

Some work supporting our results was performed by Seethal (2005), whose case study of the Stellenbosch municipality (in the Western Cape) shows that political 'regime change' 
in a municipality threatens the appointments of senior officials. A study conducted for the South African Local Government Association (SALGA) on the influence of internal municipal governance arrangements and practice on municipal service delivery also reveals interesting parallels to our work, finding that "of the most contested relationships that negatively affects the proper functioning of a municipality, is the interference of political parties outside the established political channels" (de Visser et al., 2009: 34).

Romero-Lankao (2007) mentions that environmental efforts are constrained by institutional instability in terms of high turnover rates among government personnel that render training efforts ineffective; Roberts (2010) notes that leadership change had slowed down adaptation efforts in the health sector of Durban's municipality (neither author mentions the reason for turnover/leadership change). The literature suggests that the political nature of local government means that all decisions, including climate adaptation, are affected by political interests (Keen et al., 2006). However, not much research appears to exist on the influence of politics on local government functioning, as the field of party politics at the local level is strongly under-researched (Bénit-Gbaffou, 2012; Fourchard, 2012). Our works suggests that political instability can greatly disrupt the operations of a municipality, and that political stability can be an important factor for environmental sustainability through its influence on municipal functioning.

\section{Adaptation mainstreaming at the local government level}

Our research suggests a number of factors critical to adaptation mainstreaming in local government. Leadership is key, and our work suggests that while political leadership is essential for driving rapid change, administrative leadership can be essential for proactive change. The impacts of climate change, and their costs, often provide the strongest initial catalyst for municipalities to transform their development paths towards more sustainable paths. This transformation is assisted by the recognition that the environment has value, and by a greater understanding of the concept of ecosystem services. The understanding of both climate change and ecosystem services concepts is related to the availability, to a municipality, of an environmental knowledge base. Larger municipalities are likely to have a larger revenue base and hence greater resource availability. However, advantages from denser social networks (which also help municipalities fight the pervasive 'silo mentality' problem) can accrue to small municipalities. Finally, political stability greatly benefits a municipality's ability to make decisions and see them through, and thus perform.

The implications of these factors are insightful for achieving successful adaptation mainstreaming in other locations. At the institutional level, deficiencies in leadership, knowledge and information regarding climate adaptation issues needs to be targeted. It is important to emphasize that the development of the leadership and knowledge capacities 
of municipalities can be addressed through planning at various levels.

First, since political champions are fundamental for rapid change, it may prove especially important to focus on the education of councillors (particularly senior councillors). National governments have the option to mandate appropriate training for councillors (e.g. in South Africa the brief period of councillor training is not compulsory nor is it focused on environmental issues). Local municipalities should explicitly consider providing specific training to their senior councillors, as occurred in Hessequa. Organizations and stakeholders working closely with municipalities (such as ICLEI, Local Governments for Sustainability) could also focus more explicitly upon interacting with senior politicians.

Second, political champions should be coupled with administrative champions, as environmentally-qualified staff are likely to have greater knowledge of the complex climate change issues. Thus, national governments need to mandate the consideration of climate change issues within local governments so as to render compulsory the appointment of staff with the relevant expertise. Exogenous forces, such as national regulations, have been shown to be successful at providing the motivation for local governments to engage in climate action (Carmin et al., 2012). Meanwhile, local councils should identify suitable existing staff to champion the climate change agenda, introducing it as part of their Key Performance Indicators, and provide for relevant training opportunities where necessary.

Third, it is critical for municipalities to (i) recognize and act upon the costs of climate change before they happen (especially considering the short-term planning cycles of government), and (ii) recognize the value in the natural environment. To this end, the availability of a knowledge base is key. National and provincial governments can more explicitly consider how to facilitate the inclusion of local municipalities into networks: climate change networks have proven critical to the development of climate governance in municipalities, from transnational networks (refer to examples in Bulkeley 2010) to local level networks such as Cape Town's Climate Change Think Tank. National and provincial governments also have to option to establish networks for local municipalities, especially where these are not available or readily accessible: for instance, the Western Cape provincial government has established a Climate Change Municipal Support Programme for municipalities in the province (Western Cape Government 2013). The greatest need is likely to lie in municipalities outside of the largest cities, where networks of practitioners, NGOs, academics, consultants and other organizations are typically concentrated. Hence these areas ought to be targeted by national/provincial governments and other stakeholders working with municipalities. Finally, municipalities themselves, especially those small and isolated, must consider what networks/partnerships they could join or attempt to establish: our Hessequa municipality case demonstrates that 
partnerships can be successful even where partners are remotely located.

Our case studies also provide additional insights into constraints and opportunities posed by institutional structures. First, local governments must internally plan for administrative champions to be senior and well-resourced enough to be able to effect change: in the course of our wider research we found environmental staff to often be relatively junior members of staff, with neither the resources nor power to strongly influence the municipality. The historic tendency of municipalities to view climate change as an environmental problem (Measham et al., 2011) affects its mainstreaming, given that environmental issues are assigned a lower priority than other issues (e.g. IDS \& Tearfund, 2006; Hardoy \& Romero Lankao, 2011; Wilhelm-Rechmann et al., 2012). Thus, environmental departments are often not assigned much influence or resources (see also for e.g. Dalal-Clayton \& Bass, 2009; Hardoy \& Romero-Lankao, 2011; Ziervogel \& Parnell, 2012). Hence, municipalities can benefit by locating administrative champions for climate change in departments other than environmental departments, or at least in addition to.

Second, the issue of institutional size offers both challenges and opportunities to municipalities. Institutional 'silos', as mentioned earlier, are a historic problem, and our case studies suggest that larger municipalities may need to focus more than others on the challenge of breaking institutional silos down. Smaller municipalities, instead, will likely need to focus more upon the problem of scarce resources. Lack of resources is especially pertinent to the adaptation mainstreaming domain given that climate adaptation competes for funding amongst other needs which can seem more pressing for local councils (e.g. Measham et al., 2011), particularly in developing nations with their high development needs. Hence even if the need for climate adaptation is acknowledged in legislation, policies and plans, it may be underrepresented at the implementation level in small municipalities.

Perhaps in small municipalities the education of political leaders should constitute even more of a priority, given that the support or otherwise of councillors (whose mandate it is to set goals and allocate resources) plays a huge role in climate adaptation at the local scale.

Third, the results on the political arrangements of municipalities suggest that mainstreaming is strengthened by political stability. One option to address political instability resulting from a political party system might be to establish a professional career civil service, whereby government staff would remain in post through successive political administrations. This option might provide greater continuity to policies and practices for environmental sustainability in a municipality (Montero et al., 2006). In South Africa's case, this might mean de-linking the appointment of senior officials from 
political office-bearers and considering alternative strategies for appointing the heads of the municipal administration.

\section{Conclusions}

Much research has focused on examining how barriers to action can constrain the ability of municipalities to pursue climate change adaptation. An important step in shifting unsustainable development paths is to identify critical factors that create opportunities for action. Our case studies show that, by specifying and analyzing the enabling factors present in cases of successful municipal adaptation, it is possible to identify priority areas of intervention to maximize the success of adaptation mainstreaming. Although we have focused on adaptation specifically in this paper, we expect that these enabling factors will be generally relevant to the mainstreaming of other sustainable development challenges.

Our findings highlight some critical knowledge gaps for future research to address. First, institutional size, and the social network dynamics of a municipality, will influence the manner in which these institutions are able to mainstream adaptation. However, little is still known about the specific influence of these factors. For example, will intermediatesize municipalities struggle to mainstream adaptation due to both a lack of resources and strong institutional silos, or will they find it easier because their size allows them both sufficient resources and communication between departments? Second, the issue of political stability and party politics effects on local government functioning require much

further attention from researchers, especially if we are to learn how to limit the destabilizing effects of political changes within municipalities.

\section{References}

Anderson, P. and Elmqvist, T., 2012. Urban ecological and social-ecological research in the City of Cape Town: insights emerging from an Urban Ecology CityLab. Ecology and Society, 17(4). 23. http://dx.doi.org/10.5751/ES-05076-170423.

Anguelovski, I. and Carmin, J., 2011. Something borrowed, everything new: innovation and institutionalization in urban climate governance. Current Opinion in Environmental Sustainability, 3 (3). 169-175.

Athey, G., Glossop, C., Harrison, B., Nathan, M. and Webber, C., 2007. Innovation and the city. NESTA Research Report, NESTA, London.

Baker, I., Peterson, A., Brown, G. and McAlpinea, C., 2012. Local government response to the impacts of climate change: an evaluation of local climate adaptation plans. Landscape and Urban Planning, 107 (2). 127-136.

Bénit-Gbaffou, C., 2012. Party politics, civil society and local democracy - reflections 
from Johannesburg. Geoforum, 43 (2). 178-189.

Bulkeley, H., 2010. Cities and the governing of climate change. Annual Review of Environment and Resources, 35, 229-253.

Burch, S., 2010. Transforming barriers into enablers of action on climate change: insights from three municipal case studies in British Columbia, Canada. Global Environmental Change, 20 (2). 287-197.

Carmin, J., Anguelovski, I. and Roberts, D., 2012. Urban climate adaptation in the Global South: planning in an emerging policy domain. Journal of Planning Education and Research, 32(1). 18-32.

City of Cape Town, 2012. Environmental resource economics. http://www.capetown.gov.za/en/EnvironmentalResourceManagement/projects/Pages/Env iro nmentalResourceEconomics.aspx [accessed 15 June 2013].

Costanza, R., D'arge, R., De Groot, R., Farber, S., Grasso, M., Hannon, B., Limburg, K. Naeem, S., O'Neill, R. V., Paruelo, J., Raskin, R. G., Sutton, P. and Van Den Belt, M., 1997. The value of the world's ecosystem services and natural capital. Nature, 387(630). 253-260.

Critchfield, T. S. and Kollins, S. H., 2001. Temporal discounting: basic research and the analysis of socially important behaviour. Journal of Applied Behaviour Analysis, 34(1). $101-122$.

de Visser, J., Steytler, N. and May, A., 2009. The quality of local democracies a study into the functionality of municipal governance arrangements. Report prepared for SALGA and GTZ, Community Law Centre, University of the Western Cape, Bellville, South Africa.

de Wit, M. P., Van Zyl, H., Crookes, D. J., Blignaut, J. N., Jayiya, T., Goiset, V. and Mahumani, B. K., 2009. Investing in natural assets: a business case for the environment in the City of Cape Town. Report prepared for the City of Cape Town, Natural Value Joint Venture, Brackenfell, South Africa.

Dalal-Clayton, B. and Bass, S., 2009. The challenges of environmental mainstreaming: experience of integrating environment into development institutions and decisions. Environmental Governance No. 3, International Institute for Environment and Development, London.

Eakin, E. and Lemos, M. C., 2006. Adaptation and the state: Latin America and the challenge of capacity-building under globalization. Global Environmental Change, 16(1): 
$7-18$.

Fourchard, L., 2012. Security and party politics in Cape Town. Geoforum, 43(1). 199206.

Froestad, J., Shearing, C., Herbstein, T. and Grimwood, S., 2012. City of Cape Town Solar Water Heater Bylaw: barriers to implementation. Climate Change at the city scale: impacts, mitigation and adaptation in Cape Town, A. Cartwright, S. Parnell, G. Oelofse and S. Ward (eds.). Routledge, Abingdon, UK. 244-262.

Gómez-Baggethun, E. and Barton, D. N., 2013. Classifying and valuing ecosystem services for urban planning. Ecological Economics, in press. doi: 10.1016/j.ecolecon.2012.08.019.

Granovetter, M., 2005. The impact of social structure on economic outcomes. Journal of Economic Perspectives, 19(1). 33-50.

Hardoy, J. and Romero Lankao, P., 2011. Latin American cities and climate change: challenges and options to mitigation and adaptation responses. Current Opinion in Environmental Sustainability, 3(3). 158-163.

Hirsh, J. B., Morisano, D. and Peterson, J. B., 2008. Delay discounting: interactions between personality and cognitive ability. Journal of Research in Personality, 42(6). 1646-1650.

Holgate, C., 2007. Factors and actors in climate change mitigation: a tale of two South African cities. Local Environment, 12(5). 471-484.

IDS and Tearfund, 2006. Overcoming the barriers: mainstreaming climate change adaptation in developing countries. Tearfund Climate Change Briefing Paper 1, Tearfund, Middlesex, UK.

Kalenscher, T. and Pennartz, C. M. A., 2008. Is a bird in the hand worth two in the future? The neuroeconomics of intertemporal decision-making. Progress in Neurobiology, 84(3). 284-315.

Keen, M., Mahanty, S. and Sauvage, J., 2006. Sustainability assessment and local government: achieving innovation through practitioner networks. Local Environment, 11(2). 201-216.

Kithiia, J., 2011. Climate change risk responses in East African cities: need, barriers and opportunities. Current Opinion in Environmental Sustainability, 3(3). 176-180. 
McLaughlin, E., 2012. Electoral regimes and party-switching: floor-crossing in South Africa's local legislatures. Party Politics, 18(4). 563-579.

Measham, T. G., Preston, B. L., Smith, T. F., Brooke, C., Gorddard, R., Withycombe, G., and Morrison, C., 2011. Adapting to climate change through local municipal planning: barriers and challenges. Mitigation and Adaptation Strategies for Global Change, 21(8). $1381-2386$.

Midgley, G. F., Chapman, R. A., Hewitson, B., Johnston, P., de Wit, M., Ziervogel, G. Mukheibir, P., van Niekerk, L., Tadross, M., van Wilgen, B. W., Kgope, B., Morant, P. D.,

Theron, A., Scholes, R.J. and Forsyth, G. G., 2005. A status quo, vulnerability and adaptation assessment of the physical and socio-economic effects of climate change in the Western Cape. Report to the Western Cape Government, CSIR Report No. ENV-S-C 2005- 073, CSIR, Stellenbosch, South Africa.

Montero, S. G., Castellón, E. S., Rivera, L. M. M., Ruvalcaba, S. G. and Llamas, J. J., 2006. Collaborative governance for sustainable water resources management: the experience of the Inter-municipal Initiative for the Integrated Management of the Ayuquila River Basin, Mexico. Environment and Urbanization, 18(2), 297-313.

Mukheibir, P. and Ziervogel, G., 2007. Developing a Municipal Adaptation Plan (MAP) for climate change: the city of Cape Town. Environment and Urbanization, 19(1). 143158.

O'Farrell, P. J., Anderson, P. M. L., Le Maitre, D. C. and Holmes, P. M., 2012. Insights and opportunities offered by a rapid ecosystem service assessment in promoting a conservation agenda in an urban biodiversity hotspot. Ecology and Society, 17(3). 27. http://dx.doi.org/10.5751/ES-04886-170327

Pelling, M. and Dill, K., 2010. Tipping points for change in the adaptation of sociopolitical regimes. Progress in Human Geography, 34(1). 21-37.

Qi, Y., Ma, L., Zhang, H. and Li, H., 2008. Translating a global issue into local priority: China's local government response to climate change. Journal of Environment and Development, 17(4). 379-400.

Roberts, D., 2008. Thinking globally, acting locally -- institutionalizing climate change at the local government level in Durban, South Africa. Environment and Urbanization, 20(2). 521-357.

Roberts, D., 2010. Prioritizing climate change adaptation and local level resilience in 
Durban, South Africa. Environment and Urbanization, 22(2). 397-413.

Roberts, D., Boon, R., Diederichs, N., Douwes, E., Govender, N., Mcinnes, A., Mclean, C., O'Donoghue, S. and Spires, M., 2012. Exploring ecosystem-based adaptation in Durban, South Africa: "learning-by-doing" at the local government coal face. Environment and Urbanization. 24(1), 167-195.

Roberts, N. C., 2011. Beyond smokestacks and silos: open-source, web-enabled coordination in organizations and networks. Public Administration Review, 71(5). 677693.

Romero-Lankao, P., 2007. How do local governments in Mexico City manage global warming? Local Environment, 12(5). 519-535.

Romero-Lankao, P., 2012. Governing carbon and climate in the cities: an overview of policy and planning challenges and options. European Planning Studies, 20(1). 7-26.

Romero-Lankao, P. and Dodman, D., 2011. Cities in transition: transforming urban centers from hotbeds of GHG emissions and vulnerability to seedbeds of sustainability and resilience. Current Opinion in Environmental Sustainability, 3(3). 113-120.

Rosenzweig, C. and Solecki, W., 2010. Introduction to climate change adaptation in New York City: building a risk management response. Annals of the New York Academy of Sciences, 1196. 13-17.

Roy, M., 2009. Planning for sustainable urbanisation in fast growing cities: mitigation and adaptation issues addressed in Dhaka, Bangladesh. Habitat International, 33(3). 276286.

Sanchez-Rodriguez, R., 2009. Learning to adapt to climate change in urban areas. A review of recent contributions. Current Opinion in Environmental Sustainability, 1(2). 201-206.

Seethal, C., 2005. Postmodern urban politics in South Africa: the case of Stellenbosch (2000-2004). South African Geographical Journal, 87(2). 141-151.

SPC (Secretariat of the Pacific Community) and GTZ (Deutsche Gesellschaft für Technische Zusammenarbeit), 2010. Mainstreaming processes for climate change adaptation: collection of best practices. Secretariat of the Pacific Community, Suva, Fiji.

Tenkasi, R. V. and Chesmore, M. C., 2003. Social networks and planned organizational change: the impact of strong network ties on effective change implementation and use. Journal of Applied Behavioral Science, 39(3). 281-300. 
Western Cape Government, 2013. Climate change municipal support programme. http://eadp.westerncape.gov.za/municipal-support-portal/climate-change-municipalsupport- forum [accessed 10 Nov 2013].

Wilhelm-Rechmann, A., Cowling, R. M. \& Difford M. (2014). Using social marketing concepts to promote the integration of systematic conservation plans in land use planning in South Africa. Oryx, 48(1), 71-79.

Ziervogel, G. and Parnell, S., 2012. South African coastal cities: governance responses to climate change adaptation. Climate change at the city scale: impacts, mitigation and adaptation in Cape Town, A. Cartwright, S. Parnell, G. Oelofse and S. Ward (eds.). Routledge, Abingdon, UK. 223-243.

Ziervogel, G., Shale, M. and Du, M., 2010. Climate change adaptation in a developing country context: the case of urban water supply in Cape Town. Climate and Development, 2(2). 94-110.

\section{Acknowledgements}

This work is based upon research supported by the National Research Foundation (NRF) of South Africa, the Claude Leon Foundation, Nelson Mandela Metropolitan University, and Santam Insurance Company Limited. All the respondents who gave up time to be interviewed are gratefully acknowledged. We thank two anonymous reviewers for their valuable comments. The authors acknowledge that opinions, findings and conclusions or recommendations expressed in this publication are that of the author(s), and that the NRF, Claude Leon Foundation, Nelson Mandela Metropolitan University and Santam Insurance Company Limited accept no liability whatsoever in this regard. 